НЕЙЧЕВ О. В., кандидат технічних наук, доцент, СОСУНОВ О. О., кандидат технічних наук, доцент, ХІСМАТУЛІН В. Ш., кандидат технічних наук, професор (Український державний університет залізничного транспорту)

\title{
Безпечний пристрій сполучення 3 індукційним мажоритарним реле
}

У статті запропоновано принци дії і структуру безпечного мажоритарного пристрою сполучення (ПС) резервованих систем керування з виконавчими об'єктами, здатного реалізовувати логіку керування 2 з 2, 233 з високими показниками функиійної безпечності; обгрунтовано можливість і доцільність використання в складі ПС трьохелементних індукиійних реле, щзо функиіонують за принцииом трифазного асинхронного двигуна; сформульовано вимоги до їх параметрів; запропоновано електричну схему функиіональних перетворювачів ПС $i$ схему підключення мажоритарного реле до їх виходів.

Ключові слова: мажоритарний елемент, мажоритарний пристрій, пристрій мажоритарного резервування, індукиійне реле, безпечний пристрій сполучення.

\begin{abstract}
Вступ
Одним із завдань, що вирішуються під час розроблення систем керування технологічними процесами, є сполучення мікроелектронної апаратури 3 виконавчими пристроями. Його складність значною мірою визначається вимогами, що висуваються до надійності проектованих систем, і зокрема функційної безпечності. Відомо, що найбільш поширеним методом кардинального підвищення надійності систем автоматизації $є$ резервування [1]. Тому питанням розробки та вдосконалення пристроїв сполучення (ПС), призначених для використання в складі резервованих систем керування, присвячено значну кількість літературних джерел [2, 4-7]. Особлива увага приділяється синтезу безпечних пристроїв сполучення для систем керування відповідальними технологічними процесами.
\end{abstract}

\footnotetext{
Аналіз останніх досліджень і публікацій

Концепція побудови безпечної системи залежить від властивостей елементної бази [2]. Якщо використовуються елементи 3 несиметричними відмовами, цю концепцію можна сформулювати таким чином: всі несправності, ймовірність виникнення яких необхідно враховувати, не повинні призводити до небезпечних відмов. Такий підхід застосовується при проектуванні класичних систем залізничної автоматики, що використовують як елементну базу реле першого класу надійності [3]. Набагато складніше вирішується завдання забезпечення безпеки в системах, побудованих з використанням елементної бази із симетричними відмовами. При тому що сучасні
}

апаратні засоби більш надійні у порівнянні з релейноконтактними, ймовірністю виникнення їх відмов не можна знехтувати. У цій ситуації загальна концепція побудови безпечних систем формулюється так: одноразові відмови апаратних і програмних засобів не мають призводити до небезпечних відмов i їх необхідно виявляти на робочих або тестових впливах не пізніше, ніж у системі виникне друга відмова. Цю концепцію задовольняють системи, що мають у своєму складі стійке до відмов ядро, безпечні пристрої сполучення, безпечні пристрої комутації виконавчих об'єктів (ВО), розвинену підсистему діагностування.

Специфічні для відповідальних дискретних систем вимоги безпеки не дають змоги використовувати для побудови керуючих ЕОМ або контролерів пристрої сполучення, що випускаються промисловістю, тому в комп'ютерних системах безпеки як ПС застосовують функціональні перетворювачі (ФП) з несиметричною відмовою i програмно-апаратним контролем справності елементів [4, 5].

За елементною базою розрізняють релейні i безконтактні пристрої сполучення. В релейних ПС комутація електричних кіл виконавчих об'єктів здійснюється контактами реле першого класу надійності, що вмикаються/вимикаються, як правило, безконтактними функціональними перетворювачами малої потужності [5]. Недоліком такого рішення $€$ незадовільні масогабаритні показники систем, особливо, якщо ПС виконує функцію порівняння 2 з 2 або 2 3 3. В безконтактних пристроях сполучення безпосереднє керування об'єктами здійснюється за допомогою напівпровідникових елементів комутації 
або функціональних перетворювачів відповідної потужності. Якщо комутація кола ВО здійснюється за допомогою напівпровідникових елементів, необхідний безперервний контроль справності комутаційної схеми iз залученням для цього додаткових ресурсів обчислювальних засобів і негайне відключення живлення групи виконавчих пристроїв у разі виявлення короткого замикання ключових елементів [5]. Очевидно, що для відключення живлення в таких випадках використовуються схемні рішення 3 безпечними ФП i релейними комутаційними елементами. Ще одним недоліком безконтактного сполучення $\epsilon$ наявність істотних втрат енергії в перетворювальних схемах, які пропорційні споживаній виконавчими пристроями енергії. Невисокий ККД перетворювальних схем призводить не тільки до перевитрати електроенергії, а й до значного тепловиділення. Це, у свою чергу, накладає обмеження на щільність розміщення обладнання i потребує додаткових заходів для відведення тепла. Крім того, потужні перетворювальні схеми формують напругу прямокутної форми 3 широким спектром гармонік, що ускладнює вирішення проблем електромагнітної сумісності.

Таким чином, відомі схемотехнічні рішення, що забезпечують як безконтактне сполучення керуючих обчислювальних комплексів з об'єктами, так і релейне на базі реле першого класу надійності, не вільні від недоліків, тому залишається актуальним завдання пошуку інших рішень [5].

Метою дослідження $€$ синтез пристрою 3 несиметричною відмовою для сполучення дво- i триканальних обчислювальних комплексів систем керування відповідальними технологічними процесами 3 виконавчими об'єктами, здатного реалізовувати логіку керування 2 з 2 і 2 з 3 відповідно.

Завданнями дослідження є: визначення принципу дії і структури безпечного мажоритарного пристрою сполучення; теоретичне обгрунтування можливості його практичної реалізації; розроблення схемних i алгоритмічних рішень для досягнення зазначеної мети.

\begin{tabular}{cccc}
\hline Основна частина & & \\
\hline Розглянемо можливі & варіанти & \multicolumn{2}{c}{ сполучення } \\
триканальної мажоритарної & системи & керування
\end{tabular}
виконавчими об'єктами і логікою прийняття рішення 233.

На рис. 1 наведено структурну схему триканальної системи з релейно-контактним пристроєм сполучення. Для вмикання ВО канали обробки інформації К1, К2, К3 мають надати керуючий вплив (безперервну послідовність імпульсів, наприклад) на входи відповідних функціональних перетворювачів ФП1 ФП3, до виходів яких підключені реле Р1 - Р3. Вмикання ВО відбувається при формуванні команд управління не менше, ніж двома каналами, що забезпечується контактними парами $\mathrm{P} 1 \wedge \mathrm{P} 2, \mathrm{P} 1 \wedge \mathrm{P} 3$, P2 $\wedge$ Р3. Вузол вхідного перетворювача Вх. п призначений для формування достовірних вхідних сигналів про стан ВО. Блоки ФП1-ФПЗ можуть бути побудовані за схемою трансформаторного або конденсаторного перетворювача 3 несиметричною відмовою, а як Р1-Р3 - використовуватися реле першого класу надійності [2].

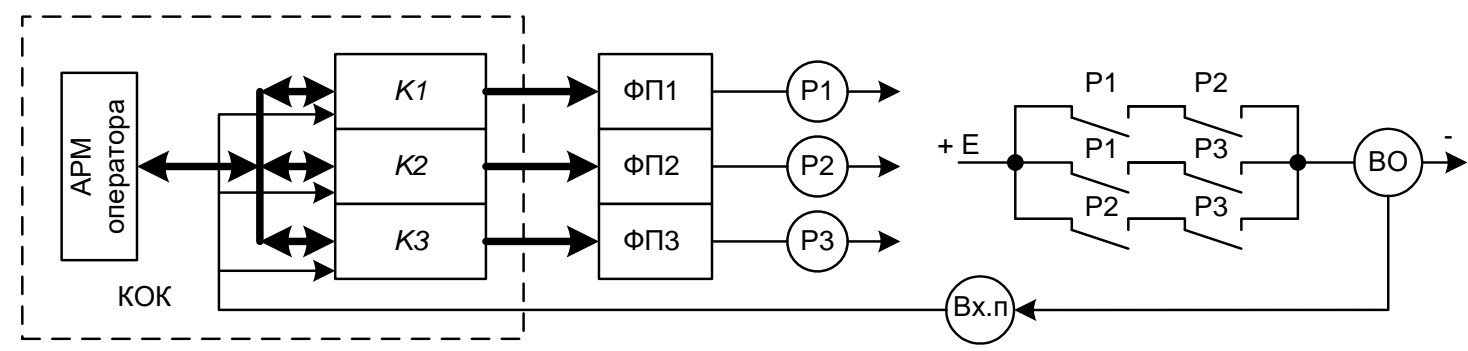

Рис. 1. Структурна схема триканальної системи керування

Перевагою такого рішення $\epsilon$ його простота i відсутність необхідності жорсткої синхронізації роботи вихідних електронних ключів каналів обробки інформації під час формування команд керування. Однак наявність трьох реле на один умовний ВО істотно збільшує вартість системи керування i, як було сказано вище, погіршує їх масогабаритні показники. Крім того, функціональні перетворювачі 3 конденсаторною або трансформаторною гальванічною розв'язкою (рис. 2,a,б) [2] мають схемні передумови до небезпечної відмови: у випадку пульсацій напруги в шинах джерела живлення + Еп можлива поява сигналу на їх виходах навіть за відсутності команд на входах. У схемі, наведеній на рис. 2,a, такий ефект буде спостерігатися при закритому VT1 (або обриві кола колектор-емітер), а в ПС 3 трансформаторною розв'язкою - при короткому замиканні VT1. Той факт, що для появи сигналу на виході ПС необхідне поєднання двох відмов, практично не позначається на кількісних показниках безпечності пристрою. Пояснюється це тим, що подібна відмова джерела живлення при справних інших елементах ПС 
зовнішніх проявів не має і може бути виявлена тільки під час перевірки 3 використанням спеціалізованих вимірювальних пристроїв - наприклад, осцилографа. Тобто 3 несправним джерелом живлення ПС може експлуатуватися досить тривалий час. Якщо протягом цього часу вийде 3 ладу ще і транзистор, можливе виникнення небезпечної ситуації.

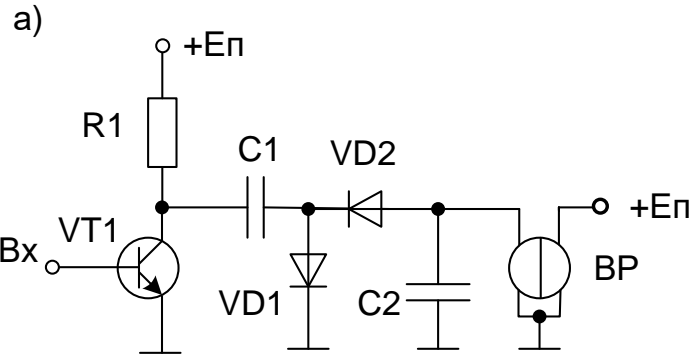

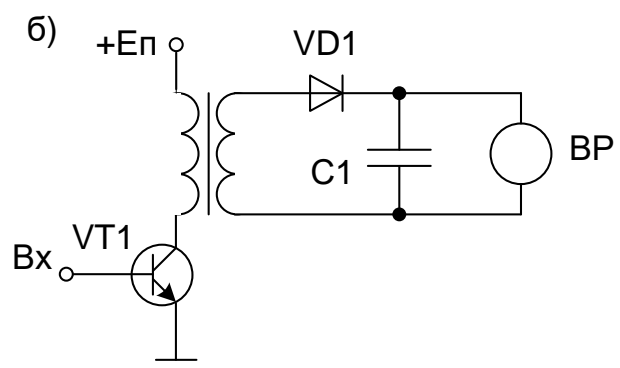

Рис. 2. Функціональні перетворювачі з конденсаторною (а) та трансформаторною (б) гальванічною розв’язкою

Відомі схеми мажоритарних ПС з безконтактними функціональними перетворювачами, що мають три входи і один вихід для вмикання реле першого класу надійності [2]. Приклад схемної реалізації такого ПС подано на рис. 3.

Пристрій працює таким чином: при синхронному надходженні безперервних послідовностей імпульсів на входи 1, 2, 3 відбувається заряд конденсаторів C1, C2, С3 протягом часу дії імпульсів. Під час паузи вони розряджаються на світлодіоди оптронів VO1, VO2 через резистори R1, R2. При цьому напруга, що впливає на них, дорівнює сумі напруг на конденсаторі i джерелі живлення. Як наслідок, фототранзистори перемикаються і формують імпульси, що надходять на перетворювач полярності (елементи С4, C5, діоди VD6, VD7), що приводить до вмикання виконавчого реле (ВР) i замикання робочого кола об'єкта управління. У випадку відсутності імпульсів на двох входах 3 трьох на світлодіоди оптронів впливає тільки напруга заряду конденсаторів, приблизно вдвічі менша, ніж у разі надходження імпульсів на всі входи. В результаті оптрони не перемикаються і ВР відпустить якір.

Однак наведена схема має ряд недоліків. Поперше, будь-яка відмова елементів перетворювача полярності, коротке замикання фототранзистора одного 3 оптронів (при тому що система управління триканальна) призведе до неможливості керування виконавчим об'єктом. По-друге, відмови елементів вхідних кіл ФП, якщо вони відбулися в одному 3 каналів, не виявляються, не діагностуються і здатні накопичуватися. Відмова елементів у будь-якому 3 двох інших каналів, якщо вона станеться, призведе до відмови системи. По-третє, перетворювач полярності це функціональний перетворювач 3 конденсаторною гальванічною розв'язкою, якому властиві зазначені вище недоліки: зменшення ємності або обрив фільтрувальних конденсаторів у джерелі живлення вихідних кіл ПС (En, рис. 3), при якому на його шинах з'являється значна змінна складова, що може привести до появи на обмотці виконавчого реле напруги, достатньої для утримання якоря реле в притягнутому стані навіть за відсутності сигналів управління на входах ПС.

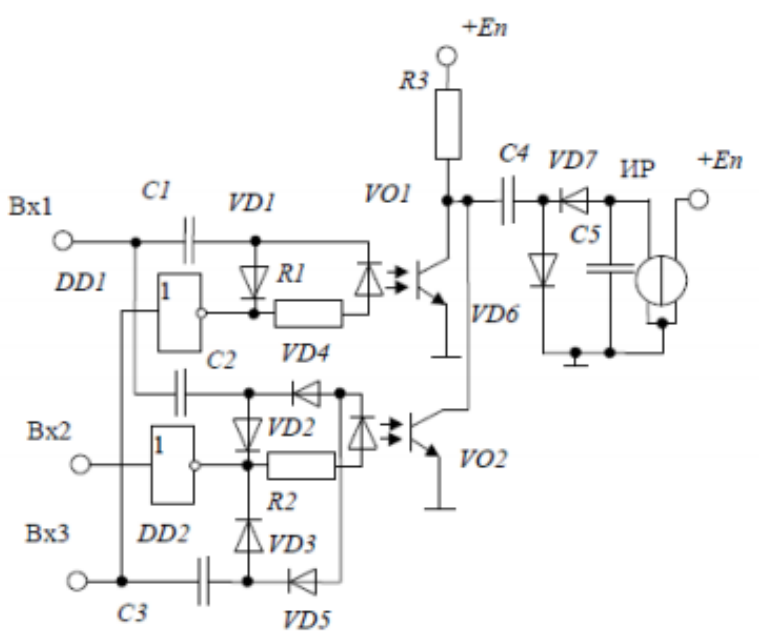

Рис. 3. Схема ПС з мажоритарним безконтактним функціональним перетворювачем

У ПС, що працюють за розглянутим принципом, мажоритування виконують функціональні перетворювачі. Радіоелектронні елементи, що сприймають сигнали управління 3 боку окремих каналів обробки інформації, формують допоміжні сигнали, які додаються попарно, і тільки збільшені за амплітудою створюють умови для появи сигналу на виході. При такому підході певні пошкодження елементів джерел живлення здатні спровокувати підвищення амплітуди допоміжних сигналів до рівня спрацьовування вихідних ключів і переведення ПС у небезпечний стан.

Перелічені вище недоліки наведених на рис. 1-3 пристроїв сполучення обумовлені використанням як 
вирішального елемента електромагнітного реле постійного струму, що реагує на амплітуду напруги, прикладеної до його обмоток. Тобто рішення про необхідність замикання/розмикання електричних кіл виконавчих пристроїв системи керування здійснюється на підставі амплітудної ознаки сигналів комутуючих пристроїв каналів керування і допоміжних сигналів функціональних перетворювачів - на підставі найбільш схильної до спотворення ознаки електричного струму.

Як альтернатива електромагнітним реле у складі пристроїв сполучення доцільне використання індукційних реле. Конструктивно індукційне реле складається 3 нерухомого магнітопроводу з обмотками і рухомої частини, виготовленої у вигляді металевого диска або циліндра. В індукційному реле крутний момент, що діє на диск або ротор, створюється в результаті взаємодії магнітних полів нерухомих обмоток, зі струмами, індукованими цими полями в рухомому елементі. Причому для отримання крутного моменту необхідно створити не менше двох магнітних потоків, зсунутих відносно один одного в просторі і в часі (за фазою). Відомі на сьогодні реле, що працюють на індукційному принципі, двоелементні вимірювальні реле струму, реле напрямку потужності, колійні двоелементні секторні реле тощо.

Як виконавче реле для пристрою сполучення, здатного реалізовувати мажоритарну функцію 2 3 3 , пропонується використовувати трьохелементне індукційне реле (рис. 4). Як окремий випадок, цей пристрій може реалізовувати функцію 2 з 2 .

ПС складається 3 функціональних перетворювачів ФП1, ФП2, ФП3 і мажоритарного реле Р (рис. 4,б). Реле містить статор з трифазною обмоткою $1.1,1.2,1.3$ і ротор 2 (рис. 4,a)). Обмотка має одну пару полюсів, а осі обмоток фаз зміщені в просторі на кут $120^{\circ}$. Вал ротора 3 містить механізм керування контактами реле 4, обмежувач кута повороту 5, а також противагу 6 для повернення ротора в початкове положення за відсутності струмів в обмотках. Вал ротора має можливість повертатися в підшипниках 7 і 8 на кут $\alpha$, величина якого визначається положенням упорів $5.1 \mathrm{i}$ 5.2 обмежувача кута повороту. Кут $\alpha$ має бути достатнім для перемикання контактів реле.
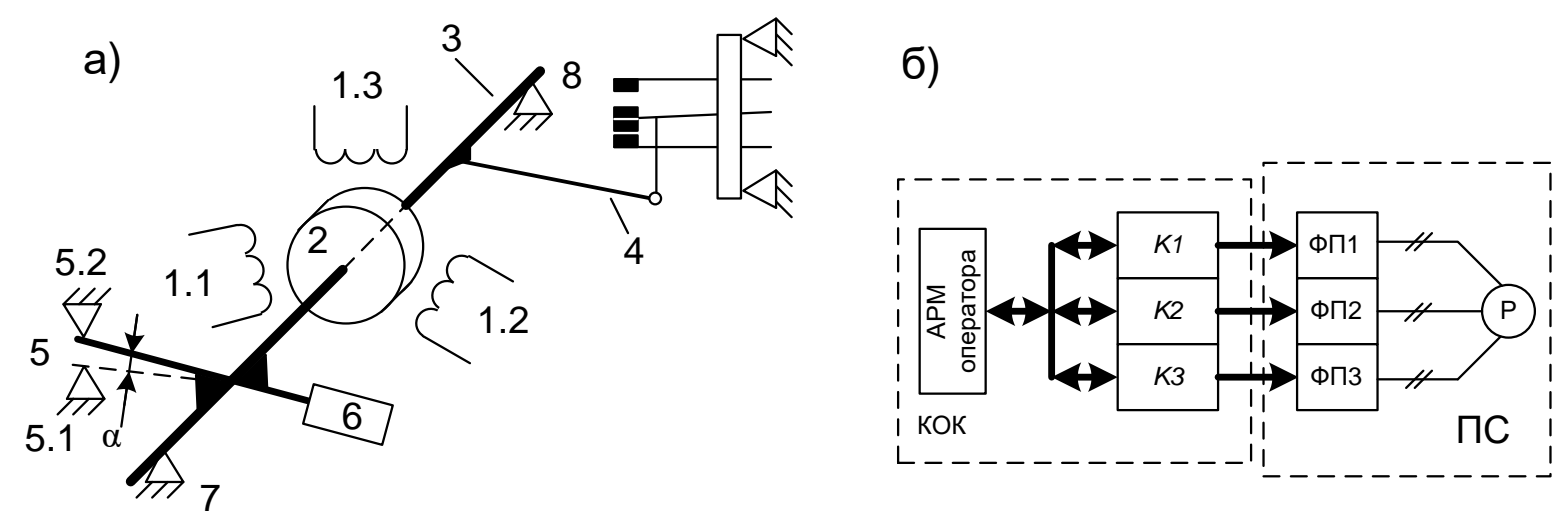

Рис. 4. Конструкція мажоритарного реле (а) і схема його підключення до функціональних перетворювачів пристрою сполучення (б)

Для вмикання реле канали обробки інформації К1, К2, К3 керуючого обчислювального комплексу мають подати безперервну послідовність імпульсів з фазовим зсувом $120^{\circ}$ на входи функціональних перетворювачів ФП1, ФП2, ФП3. Перетворювачі, у свою чергу, формують змінні однофазні напруги, що надходять на обмотки мажоритарного реле. Оскільки послідовності імпульсів на входах ФП зсунуті за фазою, змінні напруги на їх виходах, а отже, і струми в обмотках реле, будуть створювати обертове магнітне поле, яке пронизує обмотку ротора. Фазовий зсув між фронтами імпульсів має бути таким, щоб вектор магнітної індукції поля статора обертався проти годинникової стрілки (для випадку, наведеного на рис. 4). В результаті взаємодії обмотки ротора 3 індукованим у ній струмом i магнітного поля статора виникає електромагнітна сила, напрям якої збігається 3 напрямом обертання поля статора. Створюваний крутний момент долає сили опору в підшипниках $\mathrm{F}_{\text {оп, }}$ силу тяжіння противаги $\mathrm{F}_{\text {тпр, }}$ силу реакції контактної групи $\mathrm{F}_{\text {ркг }}$ і забезпечує перемикання контактів реле.

Щоб запропонований пристрій міг виконувати функцію мажоритування (замикання нормально розімкнених контактів реле відбувалося за командою мінімум двох каналів керування), його параметри, а також параметри сигналів на виході функціональних перетворювачів ФП1 ... ФП3 мають забезпечувати створення крутного моменту на валу ротора, що перевищує сумарну силу опору за наявності сигналів управління на виходах будь-яких двох ФП з трьох. У 
разі помилкової команди, сформованої одним каналом керування, крутний момент виникати не повинен.

Остання вимога, безумовно, виконується завдяки особливостям індукційних реле. У випадку формування команди на вмикання реле одним каналом змінна напруга надходить тільки на одну обмотку, що призведе до формування пульсуючого магнітного поля 3 вектором магнітної індукції, спрямованим уздовж геометричної осі котушки. Тобто обертове магнітне поле в цьому випадку відсутне і як наслідок відсутній крутний момент на валу. Жодні відмови джерела живлення функціонального перетворювача (поява пульсацій, підвищення напруги та ін.) цю картину не змінять.

Як відомо $з$ теорії асинхронних машин, крутний момент на валу двигуна пропорційний індукції магнітного поля і активній складовій струму ротора, яка у свою чергу пропорційна індукції магнітного поля. Для подальшого аналізу крутного моменту трифазного електродвигуна зручно використовувати вираз:

$M_{123}=c_{M}\left(\frac{3}{2}\right)^{2} \frac{U_{0}^{2} r_{p} s}{r_{p}^{2}+x_{p 0}^{2} s^{2}}$

де $c_{M}-$ коефіцієнт пропорційності, що враховує конструкційні особливості двигуна;

$U_{0}$ - напруга живлення;

$r_{p}$ - активний опір ротора;

$x_{p 0}-$ індуктивний опір нерухомого ротора;

$S-$ ковзання.

У складі реле ротор як у момент його вмикання, так і після перемикання контактів нерухомий. У процесі повороту ротора на кут $\alpha$ його кутова швидкість також мала. Тому можна вважати, що в усіх режимах роботи реле ковзання $S=1$.

Вираз (1) при $S=1$ набуде вигляду:

$M_{123}=c_{M}\left(\frac{3}{2}\right)^{2} \frac{U_{0}^{2} r_{p}}{r_{p}^{2}+x_{p 0}^{2}}$.

Очевидно, що для реле, на відміну від електродвигуна, визначальною характеристикою $\epsilon$ максимальний крутний момент при мінімальній споживаній потужності. Аналіз виразу (2) дає змогу зробити висновок, що за інших рівних умов $\left(U_{0}, c_{M}-\right.$ сталі), максимальний момент на валу буде забезпечуватися при $r_{p}>x_{p 0}$. Причому ця умова має забезпечуватися не за рахунок збільшення $r_{p}$, оскільки в цьому випадку момент буде зменшуватися, а за рахунок зменшення $x_{p 0}$. Оскільки

$$
x_{p 0}=\omega L p=2 \pi f L p
$$

де $L p$ - індуктивність обмотки ротора;

$\omega$ - кутова частота поля статора;

$f$ - циклічна частота поля статора,

для зменшення індуктивного опору обмотки ротора доцільно знизити частоту поля статора. Однак від частоти поля статора залежить швидкість обертання магнітного поля, швидкість обертання ротора (у двигунах), а в разі реле - його швидкодія (час вмикання). Для більшості реле залізничної автоматики цей показник перебуває в діапазоні 20 мс ... 50 мс. Для забезпечення аналогічних часових характеристик в індукційному мажоритарному реле швидкість обертання магнітного поля має бути такою, щоб за зазначений час поле поверталося на кут $\geq \alpha$ (див. рис. 4).

Нехай $\alpha=20^{\circ}$, а необхідна швидкодія (час спрацювання) - 20 мс. Мінімальна частота поля статора, при якій ця умова буде виконуватися, складатиме 2.77 Гц. Природно, що за рахунок сил опору в підшипниках, інерції мас ротора і противаги час перемикання реле виявиться більшим, однак це не буде наслідком низької швидкості обертання поля. Слід зазначити, що при такій частоті обертання поля статора відносно нерухомого ротора режим роботи реле як асинхронної машини еквівалентний роботі двигуна при частоті поля статора 50 Гц і частоті обертання ротора 47.23 оборотів за секунду. Тобто це фактично штатний режим роботи двигуна.

За відсутності напруги однієї 3 фаз обертове магнітне поле перетворюється 3 кругового в еліптичне. Еліптичне поле зручно зобразити у вигляді двох кругових полів, що обертаються в протилежних напрямках. При цьому результуючий обертальний момент, що діє на ротор, дорівнює різниці моментів від кожного кругового поля:

$M_{12}=c_{M}\left(\frac{U_{0}^{2} r_{p}}{r_{p}^{2}+x_{p 0}^{2}}-\frac{1}{4} \frac{U_{0}^{2} r_{p}}{r_{p}^{2}+x_{p 0}^{2}}\right)=c_{M} \frac{3}{4} \frac{U_{0}^{2} r_{p}}{r_{p}^{2}+x_{p 0}^{2}}$.

Коефіцієнт 1/4 у виразі (4) відображає зменшену вдвічі величину індукції магнітного поля, що обертається в протилежний бік.

Порівнюючи вирази (1) i (4), приходимо до висновку, що крутний момент за наявності тільки двох фаз втричі менший за величину моменту за наявності 
всіх трьох фаз. Оскільки параметри пристрою треба розраховувати так, щоб мінімальна величина крутного моменту перевищувала величину сумарного моменту сил опору і забезпечувала впевнене вмикання реле при двофазному керуванні, в разі формування команди одночасно трьома каналами реле буде працювати 3 триразовим перевантаженням. Тому актуальною $є$ мінімізація потужності, споживаної мажоритарним реле.

При частоті поля статора в одиниці $\Gamma_{ц}$ через активний опір ротора багаторазово перевищує його індуктивний опір $\left(r_{p}>x_{p 0}\right)$. В цьому випадку вираз (4) $з$ прийнятною похибкою можна записати у вигляді:

$M_{c o n}<M_{12}=c_{M} \frac{3}{4} \frac{U_{0}^{2} r_{p}}{r_{p}^{2}+x_{p 0}^{2}} \approx c_{M} \frac{3}{4} \frac{U_{0}^{2}}{r_{p}}$,

де $M_{c o n}$ - сумарний момент сил опору.

Як випливає 3 виразу (5), крутний момент пропорційний активній потужності, споживаній ротором $\left(U_{0}^{2} / r_{p}\right)$. Оскільки іiі мінімальне значення визначено умовою $M_{c o n}<M_{12}$, для зменшення енергоспоживання необхідно прагнути до мінімізації сил опору, що загалом очевидно, i оптимізації конструкції реле (збільшення $c_{M}$ ).

При тому що принцип дії індукційного мажоритарного реле аналогічний до принципу дії трифазного асинхронного двигуна, підключення реле за класичними для двигунів схемами (зіркою або трикутником) недоцільно. При такому підключенні реле не зможе виконувати функцію мажоритування: у випадку обриву одного з лінійних провідників, виходу 3 ладу одного 3 трьох ФП або просто за відсутності команд на виході одного з каналів керування магнітне поле припинить обертання, крутний момент зникне, а реле вимкнеться. З'єднання обмоток «зіркою» або «трикутником» призводить до зміни логіки роботи пристрою 3 « 2 3 $3 »$ в «3 3 3 3 ». Для усунення цієї проблеми обмотки індукційного реле пропонується підключати до виходів функціональних перетворювачів за шестипровідною схемою (рис. 5), тобто незалежно.

3 огляду на те що ПС з індукційним мажоритарним реле призначений для роботи у складі систем керування відповідальними технологічними процесами, алгоритмічні, схемотехнічні i конструкційні рішення, які застосовуються для його реалізації, мають виключати появу помилкового вихідного сигналу при відмовах елементів як самих ФП, так і комутуючих пристроїв у складі каналів управління. Ці вимоги задовольняють ФП на базі мостових перетворювачів [4]. Пропонована схема ПС 3 ФП мостового типу наведена на рис. 5. Безпосередню комутацію кіл живлення обмоток реле здійснюють польові транзистори VT1 ... VT4 (в першому каналі управління). Драйвери ключів верхнього і нижнього рівнів DD1, DD2 (IR2109S), маючи один вхід, забезпечують формування протифазних сигналів із захисними часовими інтервалами для керування двома транзисторами. Схема драйвера виключає одночасне відкриття транзисторів. Оптрони DD3 ... DD5 (H11L1) призначені для гальванічної ізоляції виходів типових пристроїв виведення дискретної інформації (модулів виводу) 3 напівпровідниковими пристроями ФП. Наявність у складі оптронів вбудованих тригерів Шмідта дає змогу сформувати керуючі імпульси 3 високою крутизною фронтів i зменшити час перемикання транзисторів. Входи 1.SD, 2.SD, 3.SD (shutdown) пропонується використовувати для відключення окремих функціональних перетворювачів зовнішнім «сторожем» або засобами каналів обробки інформації та управління в разі виявлення несправностей.

Послідовності керуючих імпульсів (тривалість імпульсів, інтервалів, частота надходження), що визначають форму, частоту і фазу напруги на кожній 3 обмоток реле, формуються програмно комутуючими пристроями у складі каналів керування. При низькій частоті обертання поля статора вирішення цього завдання істотно спрощується, оскільки в цьому випадку ресурс обчислювальних засобів, що залучається, виявляється мінімальним, математичне забезпечення процедур відпрацьоване і широко відоме. Однак сигнали для вмикання реле мають формуватися апаратурою каналів керування не хаотично, а 3 фіксованим фазовим зсувом, що в принципі неможливо без їх примусової синхронізації. 3 огляду на те що в сучасних системах управління безпосередню комутацію вихідних кіл здійснюють інтелектуальні пристрої (модулі виведення), питання синхронізації досить просто вирішуються саме на цьому ієрархічному рівні системи. 


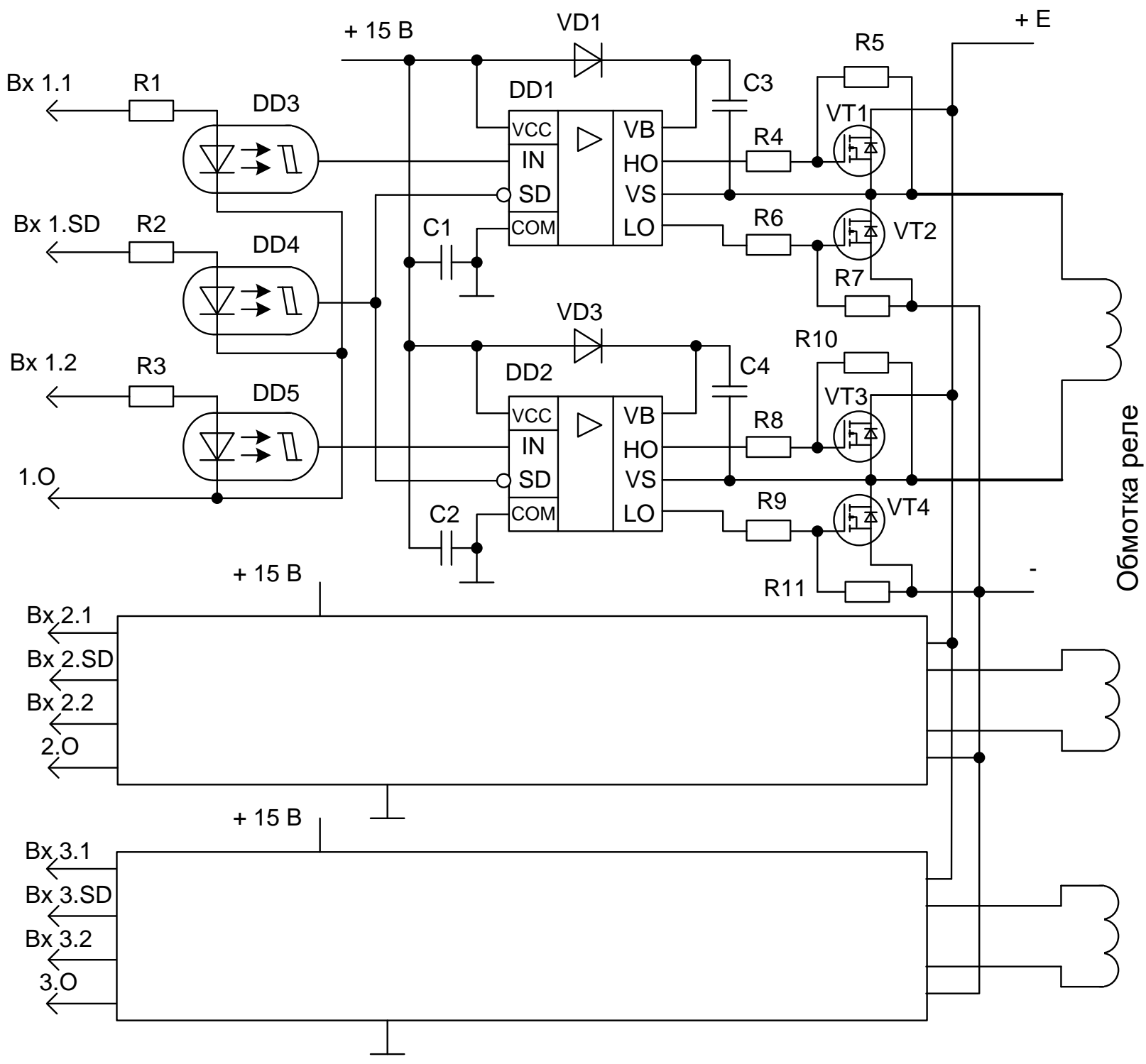

Рис. 5. Схема функціональних перетворювачів мостового типу для мажоритарного пристрою сполучення

\section{Висновки}

Відомі пристрої сполучення резервованих систем керування 3 виконавчими об'єктами, побудовані на базі функціональних перетворювачів конденсаторного або трансформаторного типу, мають ряд суттєвих недоліків, зокрема високу ймовірність хибного вмикання/невимикання виконавчого реле при виході 3 ладу певних елементів джерел живлення, внаслідок чого на його шинах з'являється значна змінна складова. У цій статті запропоновано принцип дії i структуру безпечного мажоритарного пристрою сполучення, здатного реалізовувати логіку керування 2 $32,2 \quad 3 \quad 3 \quad 3$ високими показниками функційної безпечності i некритичного до вказаних вище несправностей джерел живлення; обгрунтовано можливість і доцільність використання в складі ПС
\end{abstract}

трьохелементних індукційних реле, що функціонують за принципом трифазного асинхронного двигуна; сформульовано вимоги до їх параметрів у частині крутного моменту при дво- та трифазному керуванні; визначено мінімальну частоту обертання магнітного поля статора реле і частоту проходження імпульсів на входах функціональних перетворювачів; запропоновано електричну схему функціональних перетворювачів ПС i схему підключення мажоритарного реле до виходів ФП.

\section{Список використаних джерел}

1. Денисенко, В. В. Компьютерное управление технологическим процессом, экспериментом, оборудованием [Текст] / В. В. Денисенко. - М. : Горячая линия-Телеком, 2009. - 608 с. 
2. Федухин, А. В. Синтез систем противоаварийной автоматики с исключением опасных отказов [Текст] / А. В. Федухин // Математичні машини і системи. - 2017. - № 3. - С. 139-153.

3. Бондаренко, Б. М. Підвищення безпеки руху поїздів шляхом удосконалення процесу діагностування приладів залізничної автоматики [Текст] / Б. М. Бондаренко // Вісник Дніпропетровського національного університету залізничного транспорту. - 2012. - № 6. - С. 7-11.

4. Никитин, А. Б. Использование функциональных преобразователей с несимметричным отказом для управления электроприводами переменного тока [Текст] / А. Б. Никитин, А.Н. Ковкин // Автоматика на транспорте. - 2016. - Т. 2. - № 1. C. 7-18.

5. Никитин, А. Б. Использование малогабаритных силовых реле в безопасных устройствах сопряжения компьютерных систем железнодорожной автоматики [Текст] / А. Б. Никитин, А. Н. Ковкин, А. Д. Манаков // Автоматика на транспорте. - 2018. - Т. 4. - № 2. C. $264-278$.

6. Oya, T. A Majority-Logic Device Using an Irreversible [Text] / T. Oya, T. Asai, T. Fukui, Y. Amemiya // IEEE Trans on Nanotechnol. - 2003. Vol. 2. - no. 1. - P. 15-22.

7. Navi, K. Five-Input Majority Gate, a New Device for Quantum-Dot Cellular Automata [Text] / K. Navi, S. Sayedsalehi, R. Farazkish, M. Rahimi Azghadi // Journal of Computational and Theoretical Nanoscience. - 2010. - Vol. 7. - P. 1-8.

Нейчев О. В., Сосунов А. А., Хисматуллин В. Ш. Безопасное устройство сопряжения с индукционным мажоритарным реле.

Аннотация. В статье предложен принцип действия и структура безопасного мажоритарного устройства сопряжения (УСО) резервируемых систем управления с исполнительными объектами, способного реализовывать логику управления 2 из 2, 2 из 3 с высокими показателями функциональной безопасности; обоснована возможность и целесообразность использования в составе УСО трехэлементных индукционных реле, функционирующих по принципу трехфазного асинхронного двигателя; сформулированы требования к их параметрам; предложена электрическая схема функциональных преобразователей УСО и схема подключения мажоритарного реле к их выходам.

Ключевые слова: мажоритарный элемент, мажоритарное устройство, устройство мажоритарного резервирования, индукционное реле, безопасное устройство сопряжения.
Nejchev O., Sosunov A., Khismatulin V. Safe interface device with induction major relay.

Abstract. One of the tasks solved in the development of control systems is the interfacing of microelectronic equipment with actuators. Its complexity is largely determined by the requirements for the reliability of the designed systems, and in particular, functional safety. The most common method of significantly improving the reliability of automation systems is redundancy [1], therefore, control computing systems of critical control systems are designed to be multi-channel. In such systems, interface devices (ID) perform several functions: they implement the control logic adopted in this system, "reducing" the control signals from the outputs of individual redundancy channels to one; carry out direct switching of control circuits of objects. In railway automation systems, in addition, the ODR should with an acceptable probability eliminate the false activation of actuating objects in case of any failure of the elements of the interface device, as well as elements in the output circuits of the control channels [2]. Since the cost of control systems is proportional to the number of backup channels, the search for a compromise between the acceptable performance characteristics of the systems and their price has led to the fact that two-channel and threechannel structures operating according to scheme 2 of 2 and 2 of 3 are most widely used. It is this logic that the most common devices implement. However, the analysis of known circuit engineering, algorithmic solutions that provide both contactless and relay pairing of control computer complexes with objects suggests that they have a number of significant drawbacks, so the task of finding other solutions remains relevant [5]. This article proposes a design, substantiates the possibility and expediency of using three-element induction relays in the ID, functioning on the principle of a three-phase asynchronous motor and capable of implementing control logic 2 of 2,2 of 3 with high functional safety indicators.

Keywords: majority element, majority device, majority backup device, induction relay, safe interface.

Надійила 11.03.2019 p.

Нейчев Олег Володимирович, кандидат технічних наук, доиент кафедри «Автоматика та комп'ютерне телекерування рухом поїдів» Українського державного університету залізничного транспорту, Харків, Украӥна. E-mail: khnow_1963@ukr.net, ORCID ID: https://orcid.org/0000-0002-9093-0804

Сосунов Олександр Олексійович, кандидат технічних наук, дочент кафедри «Автоматика та комп'ютерне телекерування рухом поӥзів» Украӥнського державного університету залізничного транспорту, Харків, Україна. E-mail: $\quad$ sosunov63@kart.edu.ua, ORCID ID: https://orcid.org/0000-0003-2175-7363 
Хісматулін Володимир Шайдулович, канд. техн. наук, проф. кафедри «Автоматика та комп'ютерне телекерування рухом поїдів» Українського державного університету залізничного транспорту. Харків, Украӥна. E-mail: khisvs@kart.edu.ua ORCID ID: https://orcid.org/0000-0001-7578-1217

Nejchev Oleh Vladimirovich, candidate of technical sciences, associate professor of department of "Automat and computer telecontrol by motion of trains" of the Ukrainian state university of railway transport, Kharkiv, Ukraine. E-mail: khnow_1963@ukr.net, ORCID ID: https://orcid.org/0000-0002-9093-0804

Sosunov Aleksandr Alekseevich, candidate of technical sciences, associate professor of department of "Automat and computer telecontrol by motion of trains" of the Ukrainian state university of railway transport, Kharkiv, Ukraine. E-mail: sosunov63@kart.edu.ua, ORCID ID: https://orcid.org/0000-0003-2175-7363

Khismatulin Vladimir Shaydullovich, candidate of technical sciences, professor of department of "Automat and computer telecontrol by motion of trains" of the Ukrainian state university of railway transport, Kharkiv, Ukraine. E-mail: khisvs@kart.edu.ua, ORCID ID. https://orcid.org/0000-0001-7578-1217 